\title{
Screening of Mutations and Polymorphisms in the Glucokinase Gene in Czech Diabetic and Healthy Control Populations
}

\section{P. LUKÁŠOVÁ ${ }^{1}$, J. VČELÁK ${ }^{1}$, M. VAŇKOVÁ ${ }^{1}$, D. VEJRAŽKOVÁ ${ }^{1}$, K. ANDĚLOVÁ ${ }^{2}$, B. BENDLOVÁ ${ }^{1}$}

${ }^{1}$ Institute of Endocrinology, and ${ }^{2}$ Institute for the Care of Mother and Child, Prague, Czech Republic

Received November 12, 2007

Accepted January 28, 2008

On-line February 13, 2008

\section{Summary}

Glucokinase (GCK) plays a key role in glucose metabolism. GCK mutations are known as a pathogenic cause of maturity-onset diabetes of the young type 2 (MODY2). These mutations are also found in gestational diabetics. The aim of our study was to assess the variability of the GCK gene in the Czech diabetic and control populations. We screened all 10 exons specific for the pancreatic isoform of glucokinase (1a and 2-10) including the intron flanking regions in 722 subjects (in 12 patients with an unrecognised type of MODY and their 10 family members, 313 patients with diabetes mellitus type 2 (DM2), 141 gestational diabetics (GDM), 130 healthy offspring of diabetic parents, and 116 healthy controls without family history of DM2). In two MODY families we identified two mutations in exon 2 of the $G C K$ gene: a novel mutation Val33Ala and the previously described mutation Glu40Lys. In other subgroups (excluding MODY families) we detected only intronic variants and previously described polymorphisms in exons 6 (Tyr215Tyr) and 7 (Ser263Ser), we did not find any known GCK pathogenic mutation. We observed no difference in the frequencies of $G C K$ polymorphisms between Czech diabetic (DM2, GDM) and nondiabetic populations.

\section{Key words}

Glucokinase (GCK) • MODY2 • Mutation • Polymorphism • Gestational diabetes • Diabetes mellitus type 2

\section{Corresponding author}

Petra Lukášová, Institute of Endocrinology, Národní třída 8, 11694 Prague 1, Czech Republic. E-mail: plukasova@endo.cz

\section{Introduction}

Glucokinase comes under the hexokinase gene family and plays a key role in glucose homeostasis as a glucose sensor in pancreatic $\beta$-cells. It catalyses the initial step in these pathways - the ATP (adenosine triphosphate)-dependent phosphorylation to form glucose-6phosphate (G-6-P) (Matschinsky et al. 1993). A reduction in $\beta$-cell GCK amount or activity increases the glucose threshold for insulin secretion, causing typical fasting hyperglycemia (Byrne et al. 1994).

GCK is expressed in pancreatic $\beta$-cells, hepatocytes and variety of neural/neuroendocrine cells including pancreatic $\alpha$-cells, L- and K- gut enterocytes and selected neurons (Schuit et al. 2001). Although the GCK from pancreas, liver and brain are similar in kinetic activity and are coded by the same gene with 12 exons on chromosome 7 (7p15.3-p15.1), their primary structures in the N-terminal are different due to distinct splicing of the RNA transcript. The enzymes contain 465 amino acids and exon 1 varies in the diverse tissues due to the different promoter regions: the upstream promoter is functional in pancreas and brain, the downstream promoter is used only in liver (Stoffel et al. 1992, Gloyn 2003).

In view of its crucial role in the regulation of glucose-stimulated insulin secretion, it is possible that mutations in the $G C K$ gene can cause both hyperglycemia and hypoglycemia. Genetic studies have shown that $G C K$ mutations are responsible for three different disorders of glucose regulation. The most frequent mutations are heterozygous inactivating $G C K$ mutations known as a 
Table 1. Characterization of studied diabetic and non-diabetic groups.

\section{Type 2 diabetics Gestational diabetics Healthy offspring Control population}

\begin{tabular}{lcccc}
\hline Number (male/female) & $313(122 / 191)$ & $141(0 / 141)$ & $130(46 / 84)$ & $116(42 / 74)$ \\
Age [years] & $58.86 \pm 7.88$ & $33.14 \pm 6.44$ & $39.12 \pm 11.16$ & $31.10 \pm 10.26$ \\
BMI [kg/m ${ }^{2}$ ] & $30.53 \pm 5.53$ & $26.41 \pm 5.03$ & $25.51 \pm 4.16$ & $23.13 \pm 3.38$ \\
Fasting glucose [mmol/l] & $8.96 \pm 3.34$ & $5.3 \pm 1.85$ & $4.83 \pm 0.55$ & $4.69 \pm 0.46$ \\
Fasting insulin [mIU/l] & $15.77 \pm 10.44$ & $10.21 \pm 11.03$ & $8.88 \pm 6.01$ & $6.98 \pm 4.15$ \\
Fasting C-peptide [pmol/l] & $0.89 \pm 0.53$ & $0.73 \pm 0.32$ & $0.71 \pm 0.35$ & $0.58 \pm 0.23$ \\
HbA $_{\text {Ic [\%] }}$ & $9.08 \pm 2.36$ & $5.20 \pm 1.77$ & $5.60 \pm 1.05$ & $5.16 \pm 1.16$ \\
Glycosylated proteins [\%] & $1.61 \pm 0.32$ & $1.17 \pm 0.22$ & $1.10 \pm 0.13$ & $1.09 \pm 0.12$ \\
\hline
\end{tabular}

Values are presented as means \pm S.D.

pathogenetic cause of maturity-onset diabetes of the young type 2 (MODY2) which is characterized by mild, persistent fasting hyperglycemia, low glucose-stimulated insulin secretion, autosomal dominant inheritance and early onset (at least one affected family member with disease onset before 25 years of age) (Fajans et al. 2001). Missense mutations of $G C K$ represent the most frequent cause of MODY2; to date more than 200 mutations with distinct enzymatic characteristics have been found. These mutations were also detected in 5-6\% women with gestational diabetes (Ellard et al. 2000).

Heterozygous activating missense GCK mutations causing persistent hyperinsulinemic hypoglycemia of infancy (PHHI) and inactivating homozygous $G C K$ mutations leading to permanent neonatal diabetes mellitus (PNDM) are much less frequent (Gloyn 2003).

The aim of our study was to assess the variability of the $G C K$ gene in the Czech population and to identify possible differences of $G C K$ variants distribution between diabetic and control populations.

\section{Methods}

We studied 12 index patients affected by hyperglycemia (diabetes mellitus type 1 excluded) and with family history of higher glucose levels or diabetes in first degree relatives diagnosed before 25 years of age, according to the common criteria for the MODY diagnosis (Fajans et al. 2001), and their 10 family members.

One hundred and forty one gestational diabetic subjects (GDM; examined 0.5-1 year after the delivery) from the Institute for Mother and Child Care in Prague,
313 patients with diagnosed diabetes mellitus type 2 (DM2) and 130 healthy offspring of diabetic parents unrelated to our DM2 patients were included in the analysis. The control group consisted of 116 unrelated healthy subjects without family history of DM2. The protocol of the study was approved by the local Ethic Committee and all subjects signed informed consent.

After an overnight fast, a venous blood sample was obtained for the determination of biochemical parameters (Table 1), followed by a 75 -g oral glucose tolerance test (OGTT) in non-diabetics and GDM subjects. Blood glucose level was evaluated by the glucose oxidase method (Beckman Glucose Analyzer 2). Immunoreactive insulin was assayed in probands, which were not on insulin therapy using an immunoradiometric assay kit (Immunotech IRMA kit, Czech Rep). Serum level of C-peptide was evaluated by the immunoradiometric assay kit (Immunotech IRMA kit, Czech Rep). Glycosylated hemoglobin (HPLC BioRad, Czech Rep.) and glycosylated proteins (spectrophotometric redox reaction using nitroblue tetrazolium as a sensitive redox indicator for the specific quantification of fructosamine in alkaline solution) were also determined. OGTT derived parameters of insulin secretion (HOMA F, insulinogenic index) and insulin sensitivity (1/HOMA R, Matsuda index) were calculated (Matthews et al. 1985, Matsuda and De Fronzo 1999).

Genomic DNA was isolated from peripheral blood lymphocytes using the QIAamp ${ }^{\circledR}$ DNA Blood Kit (QIAGEN, Germany). Screening for sequence variants in all 10 exons and flanking intron regions of the $G C K$ gene was performed by SSCP (Single-stranded Conformation Polymorphism; ALFexpress II, Amersham Pharmacia Biotech, Sweden) and/or by TGGE (Temperature 
Table 2. TGGE primer sequences with GC-clamp. Cy5 labeled primers for SSCP and sequencing. Annealing temperature ( $\left.T_{a}\right)$ of amplification and temperature gradient of TGGE (Tgradient).

\begin{tabular}{|c|c|c|c|c|c|c|}
\hline Exon & Method & Primer Sequences $\left(5^{\prime} \rightarrow 3^{\prime}\right)$ & $\begin{array}{l}\mathrm{MgCl}_{2} \\
{[\mathrm{mM}]}\end{array}$ & $\begin{array}{c}\mathbf{T}_{\mathbf{a}} \\
{\left[{ }^{\circ} \mathbf{C}\right]}\end{array}$ & $\begin{array}{l}\text { Tgradient } \\
{\left[{ }^{\circ} \mathrm{C}\right]}\end{array}$ & $\begin{array}{l}\text { Size } \\
{[\text { bp] }}\end{array}$ \\
\hline $1 a$ & $\begin{array}{l}\text { SSCP and } \\
\text { sequencing }\end{array}$ & $\begin{array}{l}\text { Forward: Cy5 5'-TCA AAA GCT GTC CCC AGG TCA-3' } \\
\text { Reverse: Cy5 5'-ATG GAA TGT TGG GGA CAG GCA-3' }\end{array}$ & 1.5 & 61 & & 491 \\
\hline $1 a$ & $T G G E$ & $\begin{array}{l}\text { Forward: 5'-CGC CCG CCG CGC CCC GCG CCC GGC CCG } \\
\text { CCG CCC CCG CCC GTC CAC TTC AGA AGC CTA CTG-3' } \\
\text { Reverse: 5'-TCA GAT TCT GAG GCT CAA AC-3' } \\
\text { Stoffel et al. 1992, forward primer with GC clamp }\end{array}$ & 2 & 56 & $47-59$ & 295 \\
\hline 2 & $\begin{array}{l}\text { SSCP and } \\
\text { sequencing }\end{array}$ & $\begin{array}{l}\text { Forward: Cy5 5'-GTG AGG CCC TCG GTG TGC AGA-3' } \\
\text { Reverse: Cy5 5'-TCG GGC TGG CTG TGA GTC TGG-3' }\end{array}$ & 1.5 & 60 & & 362 \\
\hline 2 & $T G G E$ & $\begin{array}{l}\text { Forward: 5'-CGC CCG CCG CGC CCC GCG CCC GGC CCG } \\
\text { CCG CCC CCG CCC GTG CAG ATG CCT GGT GAC AGC-3' } \\
\text { Reverse: 5'-CAC AGC TGC TTC TGG ATG AG-3' } \\
\text { Stoffel et al. 1992, forward primer with GC clamp }\end{array}$ & 1.3 & 64 & $48-63$ & 330 \\
\hline 3 & $\begin{array}{l}\text { SSCP and } \\
\text { sequencing }\end{array}$ & $\begin{array}{l}\text { Forward: Cy5 5'-TAA TAT CCG GCT TCA GTC ACC } \\
\text { Reverse: Cy5 5'-CTG AGA TCC TGC ATG CCT TG-3' } \\
\text { Stoffel et al. 1992, labeled Cy5 }\end{array}$ & 2 & 62 & & 295 \\
\hline 3 & $T G G E$ & $\begin{array}{l}\text { Forward: 5'-ACC CAG CCC AAG GCC AGC CTG TG-3' } \\
\text { Reverse: 5'-CGC CCG CCG CGC CCC GCG CCC GGC CCG CCG } \\
\text { CCC CCG CCC GGT GGC ACC TCC CGT CAG GAC TAG C-3' }\end{array}$ & 3 & 69 & $50-60$ & 337 \\
\hline 4 & $\begin{array}{l}\text { SSCP and } \\
\text { sequencing }\end{array}$ & $\begin{array}{l}\text { Forward: Cy5 5'-TAG CTT GGC TTG AGG CCG TG-3' } \\
\text { Reverse: Cy5 5'-TGA AGG CAG AGT TCC TCT GG-3' } \\
\text { Stoffel et al. 1992, labeled Cy5 }\end{array}$ & 2 & 62 & & 272 \\
\hline 4 & $T G G E$ & $\begin{array}{l}\text { Forward: 5'-CGC CCG CCG CGC CCC GCG CCC GGC CCG } \\
\text { CCG CCC CCG CCC CGG CCA GGT GTT GCA GTG TCC-3' } \\
\text { Reverse: 5'-TGA AGG CAG AGT TCC TCT GG-3' } \\
\text { Reverse primer: Stoffel et al. } 1992\end{array}$ & 1.5 & 64 & $46-56$ & 341 \\
\hline 5 & $\begin{array}{l}\text { SSCP and } \\
\text { sequencing }\end{array}$ & $\begin{array}{l}\text { Forward: Cy5 5'-GCA GCC ACG AGG CCT ATC TC-3' } \\
\text { Reverse: Cy5 5'-GAG AAA GGC AGG CAG TGC TG- } 3^{\prime} \\
\text { Stoffel et al. 1992, labeled Cy5 }\end{array}$ & 1.5 & 61 & & 195 \\
\hline 5 & $T G G E$ & $\begin{array}{l}\text { Forward: 5'-TCC AGA TAT GTT AGC CAC GAG-3' } \\
\text { Reverse: 5'-CGC CCG CCG CGC CCC GCG CCC GGC CCG CCG } \\
\text { CCC CCG CCC GCC AAG GAG AAA GGC AGG CAG TG-3' }\end{array}$ & 1 & 55 & $52-62$ & 252 \\
\hline 6 & $\begin{array}{l}\text { SSCP and } \\
\text { sequencing }\end{array}$ & $\begin{array}{l}\text { Forward: Cy5 5'-CAC CCA CCC CAG CAC TGC CTG-3' } \\
\text { Reverse: Cy5 5'-AGG GAG CCT CGG CAG TCT GGA-3' }\end{array}$ & 1.5 & 62 & & 216 \\
\hline 6 & $T G G E$ & $\begin{array}{l}\text { Forward: 5'-CCA GCA CTG CAG CTT CTG TG-3' } \\
\text { Reverse: 5'-CGC CCG CCG CGC CCC GCG CCC GGC CCG CCG } \\
\text { CCC CCG CCC CGA GCC TCG GCA GTC TGG AAG-3' } \\
\text { Stoffel et al. 1992, reverse primer with GC clamp }\end{array}$ & 3 & 67 & $50-60$ & 216 \\
\hline 7 & $\begin{array}{l}\text { SSCP and } \\
\text { sequencing }\end{array}$ & $\begin{array}{l}\text { Forward: Cy5 5'-CGG GGC AGT GCA GCT CTC GCT-3' } \\
\text { Reverse: Cy5 5'-CTC CCA TCT GCC GCT GCA CCA-3' }\end{array}$ & 1.5 & 65 & & 285 \\
\hline 7 & $T G G E$ & $\begin{array}{l}\text { Forward: 5'-AGT GCA GCT CTC GCT GAC AG-3' } \\
\text { Reverse: 5'-GCC CCG CCG CGC CCC GCG CCC GGC CCG CCG } \\
\text { CCC CCG CCC CCA TCT GCC GCT GCA CCA GAG-3' } \\
\text { Stoffel et al. 1992, reverse primer with GC clamp }\end{array}$ & 2 & 65 & $54-64$ & 325 \\
\hline 8 & $\begin{array}{l}\text { SSCP and } \\
\text { sequencing }\end{array}$ & $\begin{array}{l}\text { Forward: Cy5 5'-GCC CTC CCT CGT GCC TGC TGA- 3' } \\
\text { Reverse: Cy5 5'-TCG CCC TGA GAC CAA GTC TGC- } 3^{\prime}\end{array}$ & 1 & 65 & & 278 \\
\hline 9 & $\begin{array}{l}\text { SSCP and } \\
\text { sequencing }\end{array}$ & $\begin{array}{l}\text { Forward: Cy5 5'-CCG CCG CTG GAG GGG GAT GGA- } \text { 3' }^{\prime} \\
\text { Reverse: Cy5 5'-GCG CGC TTT TTG GGC CCC ACT- } \text { 3' }^{\prime}\end{array}$ & 2 & 60 & & 352 \\
\hline 10 & $\begin{array}{l}\text { SSCP and } \\
\text { sequencing }\end{array}$ & $\begin{array}{l}\text { Forward: Cy5 5'-GTC GAC TGC GTG CAG GGC GC-3' } \\
\text { Reverse: Cy5 5'-TGT GGC ATC CTC CCT GCG CT- 3' } \\
\text { Stoffel et al. 1992, labeled Cy5 }\end{array}$ & 1.5 & 68 & & 263 \\
\hline
\end{tabular}



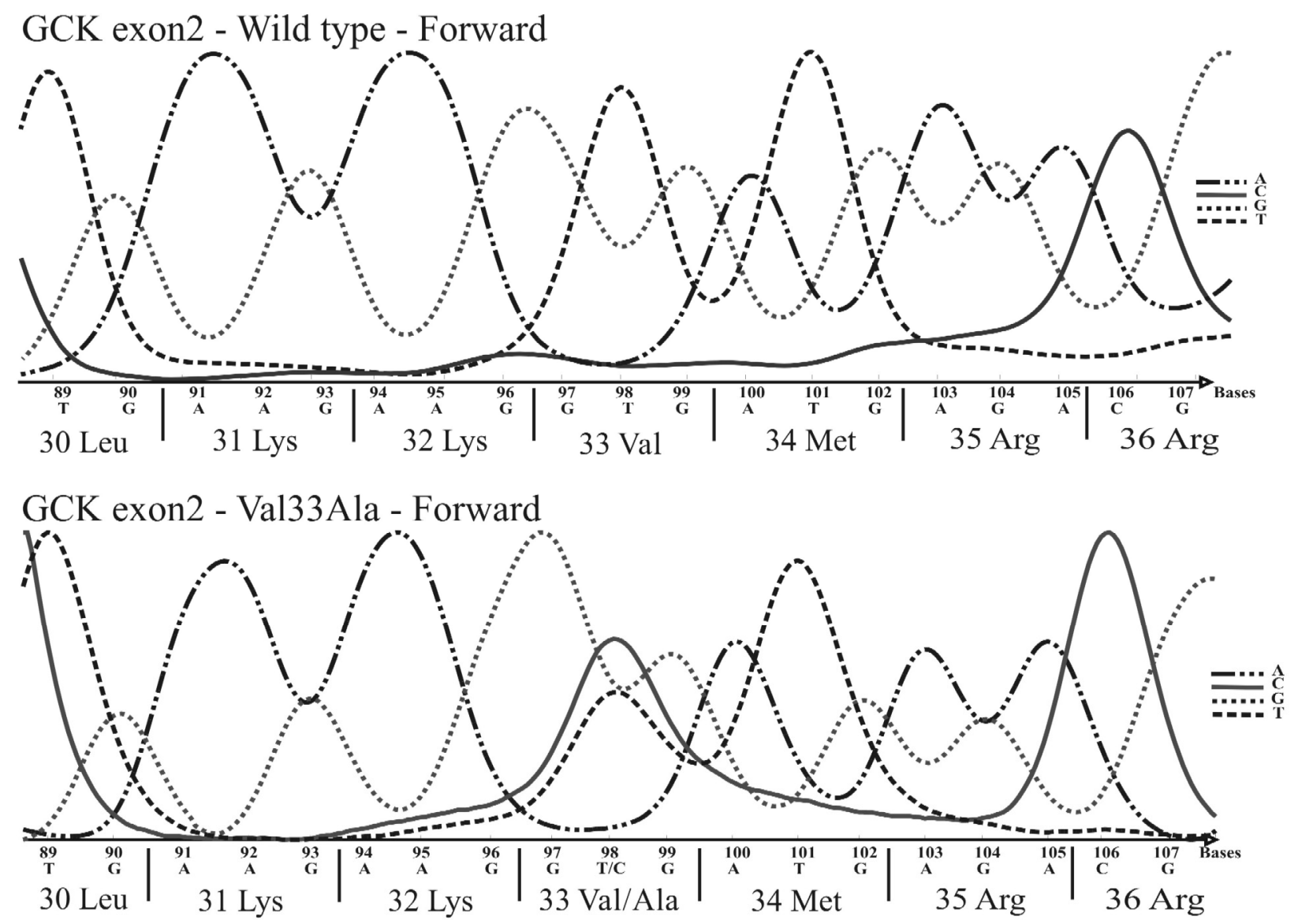

Fig. 1. The novel GCK mutation Val33Ala.

Gradient Gel Electrophoresis; TGGE MAXI, Biometra, Germany). Genomic DNA was amplified by PCR (T-Gradient Cycler, Biometra, Germany). The reaction mix $(30 \mu \mathrm{l})$ contained $1 \mathrm{x}$ reaction buffer (Perkin Elmer), 1-3 $\mathrm{mM} \mathrm{MgCl}_{2}$ (Table 2), $160 \mu \mathrm{M}$ deoxyribonucleoside triphosphates, $0.1 \mu \mathrm{M}$ of each primer (Table 2), $0.45 \mathrm{U}$ Gold AmpliTaq polymerase (Perkin Elmer) and $30 \mathrm{ng}$ of DNA. The amplification ran under the following conditions: initial denaturation at $95{ }^{\circ} \mathrm{C}$ for $10 \mathrm{~min} ; 35$ amplification cycles: $95^{\circ} \mathrm{C}$ for $30 \mathrm{~s}$, annealing temperature $\mathrm{T}_{\mathrm{a}}$ (Table 2) for $30 \mathrm{~s}$, and $72{ }^{\circ} \mathrm{C}$ for $1 \mathrm{~min}$; final elongation at $72{ }^{\circ} \mathrm{C}$ for $10 \mathrm{~min}$.

For exons 1a, 2-7, TGGE primers with GCclamps (Table 2) were chosen using the program Poland: (http://www.changbioscience.com/primo/primomel.html), which allows prediction of the impact of mutations on the melting behavior of the PCR products. Some of these primers were previously described (Stoffel et al. 1992), we linked the GC clamp and verified the melting domain. For PCR/SSCP and PCR/sequencing Cy-5 labeled primers were used (Table 2), some of them were previously described (Stoffel et al. 1992), some of them were designed by primer analysis software OLIGO ${ }^{\circledR}$ (MedProbe) (Table 2). Because of the melting profiles of exons 8-10 the TGGE method for these DNA fragments was not applicable.

PCR products for TGGE were denatured by the addition of $7 \mathrm{M}$ urea (1:1 by volume) at $95^{\circ} \mathrm{C}$ for $5 \mathrm{~min}$ and then renatured by slow cooling $\left(\Delta 1^{\circ} \mathrm{C} / 30 \mathrm{sec}\right)$ to room temperature. TGGE conditions: $8 \%$ acrylamide denaturing gel (with $7 \mathrm{M}$ urea) in $0.55 \mathrm{x}$ TBE at temperature gradient specific for each exon (Table 2), $300 \mathrm{~V}, 35 \mathrm{~mA}$ and $20 \mathrm{~W}$ for 4 hours. The gels were silver stained in a Hoefer automated gel stainer (Amersham Pharmacia Biotech, Sweden) according to the standard DNA-staining protocol.

PCR products for SSCP were denatured by addition of $95 \%$ formamide $\left(1: 2.5\right.$ by volume) at $95^{\circ} \mathrm{C}$ for 4 min. SSCP conditions: $6 \%$ non-denaturing acrylamide gel in 1x TBE at two different temperatures: $10{ }^{\circ} \mathrm{C}$ and $25^{\circ} \mathrm{C}, 1200 \mathrm{~V}, 40 \mathrm{~mA}$ and $35 \mathrm{~W}$ for 5 hours (ALFexpress II, Amersham Pharmacia Biotech, Sweden).

We used the positive controls for each exon, which were kindly provided by Dr. Thomas Selisko and 
Table 3. Positive controls that were used for screening methods.

\begin{tabular}{ll} 
Exon & Positive controls \\
\hline $\mathbf{1 a}$ & A11T $(31 \mathrm{G}>\mathrm{A})$ \\
$\mathbf{2}$ & E40fsins 20 \\
& R43fsinsC \\
$\mathbf{3}$ & Y108H $(322 \mathrm{~T}>\mathrm{C})$ \\
$\mathbf{4}$ & F150S $(449 \mathrm{~T}>\mathrm{C})$ \\
& V154fsdelTG \\
& IVS4+2del15 \\
$\mathbf{5}$ & R186X $(556 \mathrm{C}>\mathrm{T})$ \\
$\mathbf{6}$ & Y215Y $(645 \mathrm{C}>\mathrm{T} ;$ hom. $)$ \\
& Y215Y $(645 \mathrm{C}>\mathrm{T} ;$ het. $)$ \\
$\mathbf{7}$ & A259T $(775 \mathrm{G}>\mathrm{A})$ \\
& G261R $(781 \mathrm{G}>\mathrm{A})$ \\
$\mathbf{8}$ & C382Y $(1145 \mathrm{G}>\mathrm{A})$ \\
& G299R $(895 \mathrm{G}>\mathrm{C})$ \\
$\mathbf{9}$ & A384T $(1150 \mathrm{G}>\mathrm{A})$ \\
& R392C $(1174 \mathrm{C}>\mathrm{T})$ \\
& R403fsdelC \\
$\mathbf{1 0}$ & IVS9+8T $>\mathrm{C}$ \\
\hline & V455E $(1364 \mathrm{~T}>\mathrm{A})$ \\
\hline
\end{tabular}

Dr. Peter Schwarz (University Clinic Carl Gustav Carus of the Technical University Dresden, Germany) and by Prof. J. A. Maassen (Leiden University Medical Centre, The Netherlands) (Table 3).

DNA polymorphisms (bands with abnormal mobility on acrylamide gel detected by SSCP or by TGGE) were confirmed by direct sequencing in both directions. PCR products for sequencing were purified using GFX ${ }^{\mathrm{TM}}$ PCR DNA and the Gel Band Purification Kit (Amersham, Biosciences) and amplified using the Thermo Sequenase Cycle Sequencing Kit (USB), than denatured by the addition of $95 \%$ formamide (3:1 by volume) at $80^{\circ} \mathrm{C}$ for 3 minutes. Sequencing conditions: $5.5 \%$ Long Ranger ${ }^{\circledR}$ denaturating gel (with $6 \mathrm{M}$ urea) (Cambrex Bio Science Rockland) in $0.5 \mathrm{x}$ TBE at $55^{\circ} \mathrm{C}$, $1500 \mathrm{~V}, 60 \mathrm{~mA}$ and $25 \mathrm{~W}$ for 6-8 hours (ALFexpress II, Amersham Pharmacia Biotech, Sweden). Using fluorescent PCR primers these mutations were subsequently detected by an automated DNA sequencer (ALFexpress II, Amersham Pharmacia Biotech, Sweden).

\section{Results}

The basic characteristics of the study subjects are given in Table 1. Impaired fasting glucose $(>=5.6 \mathrm{mmol} / \mathrm{l})$ was found in 5 offspring of DM2, in 3 GDM. The impaired glucose tolerance (glucose in 120th min of OGTT $\geq 7.8$ and $<11.1 \mathrm{mmol} / \mathrm{l}$ ) was discovered in 4 offspring of DM2, 4 GDM and 1 control woman. All other tested subjects had normal glucose tolerance according to WHO criteria. Even if the women with diagnosed gestational diabetes improved their glucose tolerance after delivery, significantly higher fasting (ANCOVA, adjustment for age and BMI; $\mathrm{p}<0.03$ ) and OGTT stimulated glucose levels $(\mathrm{p}<0.001$, but still in normal range) in comparison with control women were detected. In GDM decreased insulin sensitivity $(1 /$ HOMA R $p<0.05)$ but sustained $\beta$-cell function was ascertained. Also in offspring of DM2 increased fasting $(p<0.03)$ and stimulated glucose levels $(p<0.03)$, significantly higher fasting insulin $(\mathrm{p}<0.006)$ and lower insulin sensitivity $(1 /$ HOMA $R, p<0.002)$ in comparison with control subjects was detected. However, insulin secretion (HOMAF, insulinogenic index) did not significantly differ between these groups.

All 10 exons specific for pancreatic glucokinase (1a and 2-10) including intron/exon boundaries were examined by SSCP and/or TGGE in 722 subjects.

Exons 1a-7 were screened by both methods: TGGE and SSCP. As we did not find suitable primers with GC-clamps for TGGE to allocate a fragment with an applicable melting domain for exons 8-10, these exons were analyzed by SSCP only. All positive controls (Table 3) were analyzed by SSCP and/or TGGE in every run. Detected gene variants are given in Table 4.

Among 12 MODY families, two GCK mutations and one intronic variant in index patients as well as in their family members were found. The first one is a novel mutation of Val33Ala $(98 \mathrm{~T}>\mathrm{C})$ in exon 2 of the $G C K$ gene in a patient with MODY (Fig. 1). This is a 12-yearold boy whose hyperglycemia was incidentally diagnosed in 10 months of age. He has mild fasting hyperglycemia and slightly increased glycosylated hemoglobin. Other biochemical parameters are in the physiological ranges. In OGTT he had fasting hyperglycemia, and the glycerin in 2 hours is on the lower border of the impaired glucose tolerance (IGT) range. However, glucose tolerance is still normal. Negative antibodies against islet cell antigens and sufficient insulin secretion disagree with DM1, MODY1 and MODY3. The genetic analysis revealed the 
Table 4. GCK gene variants in Czech diabetic and non-diabetic populations.

\begin{tabular}{|c|c|c|c|c|c|}
\hline & \multicolumn{5}{|c|}{ Type of polymorphisms / (number of carriers) } \\
\hline & $\begin{array}{c}\text { MODY } \\
(\mathrm{n}=12 \text { index patients } \\
\mathrm{n}=10 \text { family members })\end{array}$ & $\begin{array}{c}\text { Type } 2 \\
\text { diabetics } \\
(n=313)\end{array}$ & $\begin{array}{l}\text { Gestational } \\
\text { diabetics } \\
(n=141)\end{array}$ & $\begin{array}{l}\text { Healthy offspring } \\
\qquad(\mathrm{n}=130)\end{array}$ & $\begin{array}{c}\text { Control population } \\
\qquad(\mathrm{n}=116)\end{array}$ \\
\hline exon 1a & & $\begin{array}{c}\text { IVS } 1+4 T>A \\
(n=1)\end{array}$ & $\begin{array}{c}\text { IVS } 1+4 T>A \\
(n=1)\end{array}$ & $\begin{array}{c}\text { IVS } 1+4 T>A \\
(n=1)\end{array}$ & \\
\hline exon 2 & $\begin{array}{c}\text { Val33Ala }(\mathbf{9 8 T}>\mathbf{C}) \\
\qquad \begin{array}{c}(\mathbf{n}=\mathbf{1}+\mathbf{1}) \\
\text { Glu40Lys }(118 \mathrm{G}>\mathrm{A}) \\
(\mathrm{n}=1+1)\end{array}\end{array}$ & $\begin{array}{l}\text { IVS2-12 C>T } \\
\qquad(\mathrm{n}=3)\end{array}$ & $\begin{array}{l}\text { IVS2+1 G>A } \\
\qquad(\mathrm{n}=1)\end{array}$ & $\begin{array}{l}\text { IVS2-12 C>T } \\
\qquad(\mathrm{n}=1)\end{array}$ & $\begin{array}{l}\text { IVS2-12 C>T } \\
\qquad(\mathrm{n}=2)\end{array}$ \\
\hline exon 3 & & & $\begin{array}{c}\text { IVS3+9C }>\text { T } \\
(n=1)\end{array}$ & & $\begin{array}{c}\text { IVS3-23C }>\text { T } \\
(n=2)\end{array}$ \\
\hline exon 4 & $\begin{array}{c}\text { IVS4+87C }>\text { A } \\
(\mathrm{n}=2) \\
\text { IVS4+87C }>\text { A hom. } \\
(\mathrm{n}=1)\end{array}$ & & & & $\begin{array}{l}\text { IVS4+26C }>\text { A } \\
\quad(n=1)\end{array}$ \\
\hline exon 5 & & & & & \\
\hline exon 6 & & $\begin{array}{c}\text { Tyr215Tyr }(645 \mathrm{C}>\mathrm{T}) \\
(\mathrm{n}=2)\end{array}$ & $\begin{array}{c}\text { Tyr215Tyr }(645 \mathrm{C}>\mathrm{T}) \\
(\mathrm{n}=2)\end{array}$ & $\begin{array}{c}\text { Tyr215Tyr }(645 \mathrm{C}>\mathrm{T}) \\
(\mathrm{n}=1)\end{array}$ & $\begin{array}{c}\text { Tyr215Tyr }(645 \mathrm{C}>\mathrm{T}) \\
(\mathrm{n}=1)\end{array}$ \\
\hline exon 7 & & 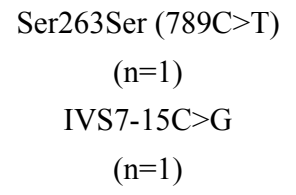 & & & \\
\hline exon 8 & & $\begin{array}{c}\text { IVS } 8+18 G>A \\
(n=2)\end{array}$ & $\begin{array}{c}\text { IVS } 8+18 G>A \\
(n=2)\end{array}$ & & \\
\hline exon 9 & $\begin{array}{c}\text { IVS } 9+8 \mathrm{~T}>\mathrm{C} \\
\quad(33.3 \%)\end{array}$ & $\begin{array}{c}\text { IVS9+8T }>C \\
(31 \%) ; \\
\text { IVS9+49G>A } \\
(7.3 \%) ; \\
\text { IVS9+8T }>C+ \\
\text { IVS9+49G }>A \\
(1.7 \%)\end{array}$ & $\begin{array}{c}\text { IVS9+8T }>C \\
(24.5 \%) ; \\
\text { IVS9+49G }>A \\
(9.2 \%) ; \\
\text { IVS9+8T }>C+ \\
\text { IVS9+49G }>A \\
(5.1 \%)\end{array}$ & $\begin{array}{c}\text { IVS9+8T }>C \\
(33.3 \%) ; \\
\text { IVS9+49G }>A \\
(11.9 \%) ; \\
\text { IVS9+8T }>C+ \\
\text { IVS9+49G }>A \\
(2.4 \%)\end{array}$ & $\begin{array}{c}\text { IVS9+8T }>C \\
(35.5 \%) ; \\
\text { IVS9+49G }>A \\
(13.1 \%) ; \\
\text { IVS9+8T }>C+ \\
\text { IVS9+49G }>A \\
(0.9 \%)\end{array}$ \\
\hline xon 1 & & & & & \\
\hline
\end{tabular}

same mutation in the proband's mother, who had exhibited gestational diabetes, later was diagnosed with DM2, which was being treated with diet so far. His maternal grandfather suffers from DM2.

The second mutation observed in our MODY families was the previously described mismatch Glu40Lys (118G $>$ A) primarily identified in the Czech population (Průhová et al. 2003). We detected this mutation in a 30-year-old man whose impaired glucose tolerance was diagnosed in 7 years of age. His mother and grandparents from the mother's side also have impaired glucose tolerance. They refused the biochemical and genetic testing.

Intronic variant IVS4 $+87 \mathrm{C}>\mathrm{A}$ was detected in a MODY 42-year-old index patient with impaired glucose tolerance and in his two offspring, in one of them in homozygous form.

In our sets of studied subjects we found ten different intronic variants and previously described polymorphisms in exons 6 and 7. With regard to the relatively low frequency of $G C K$ gene variants we did not find phenotypic differences between the probands with 
the wild type of $G C K$ gene and the probands with a $G C K$ gene variant.

\section{Discussion}

For $G C K$ mutational screening of the Czech diabetic and nondiabetic subjects two different methods were used: TGGE and SSCP. These methods can be used to screen a large number of exons or other DNA fragments when only samples with abnormal electrophoretic mobility are then subjected to DNA sequencing. Although both screening methods are based on various physical properties of DNA, we could confirm the high sensitivity of both methods and $100 \%$ concordance of TGGE and SSCP screening results consequently confirmed by direct sequencing in both directions. However, due to the plenitude of mutations in the $G C K$ gene and the limited number of positive controls, it is not completely sure that all $G C K$ gene variants were revealed in our sets of subjects.

Even though MODY is a relatively rare form of diabetes mellitus, some studies suggest that it may not be so uncommon as hypothesized and that $2-5 \%$ of patients with DM2 may in fact have MODY (Ledermann 1995). Recent data evidence supports that MODY is prevalent in approximately $1-2 \%$ of diabetic patients in Europe (Owen and Hattersley 2001). MODY2 and MODY3 represent the most common forms of MODY in Europe. The relative prevalence of MODY2 among all MODY patients varies greatly in studies from different populations: from $46-56 \%$ in France (Froguel et al. 1993, Velho et al. 1997), 41-61 \% in Italy (Massa et al. 2001, Mantovani et al. 2003), 25-41 \% in Spain (Costa et al. 2000, Barrio et al. 2002) and $31 \%$ in the Czech Republic (Průhová et al. 2003) to $11-20 \%$ in the UK (Thomson et al. 2003), $10 \%$ in Denmark (Johansen et al. 2005), $8 \%$ in Germany (Lindner et al. 1999) and $3.5 \%$ in Scandinavia (Lehto et al. 1999). This data indicates that $G C K$ mutations are more common in southern European populations than in northern Europe, where HNF-1 $\alpha$ (MODY3) mutations play the major role in MODY causes.

The clinical features of MODY2 are usually mild, and diagnosis is often accidental (Hattersley 2005). The disorder is frequently misdiagnosed and clinical diagnosis depends on the age of the patient: slim children are considered to be in the initial stages of diabetes type 1 , pregnant women are diagnosed as gestational diabetics, and older patients are classified to suffer from diabetes mellitus type 2 . This is the reason why we decided to screen $G C K$ gene variants in Czech population not only in MODY patients (including additional MODY families to those published in (Průhová et al. 2003)), but also in groups with common forms of diabetes - in type 2 and gestational diabetics in comparison with non-diabetic groups, in healthy offspring of DM2 and healthy subjects without family history of diabetes mellitus.

Among our 12 MODY families the GCK gene mutations were detected in two of them, which represents $16.7 \%$ of MODY2 genotype. In other tested groups of subjects we have not detected any $G C K$ mutations, only several polymorphisms were found.

The screening for GCK mutations and polymorphisms in patients with DM2 and in gestational diabetics in European populations was not widely performed and their prevalence indicated in a few studies was relatively low. Very few polymorphisms of the GCK gene have been reported in literature. Sequence variants in the coding and flanking regions of $G C K$ were detected in about $5 \%$ of the French DM2 subjects. In the index probands with exon variants Tyr215Tyr and Trp257Arg, diabetes had been diagnosed during pregnancy (Zouali et al. 1993). In Finland the population study of $G C K$ variants was carried out in patients with DM2 and with IGT. The following polymorphisms were found: Tyr215Tyr in $2.8 \%$ DM2 and $5 \%$ IGT; $403 \mathrm{C}>\mathrm{G}$ (5'untranslated region of exon 1a) in $16.7 \%$ DM2 and $17.5 \%$ IGT and IVS9+8T $>\mathrm{C}$ in $36 \%$ DM2 and $27.5 \%$ IGT (Laakso et al. 1995). Intronic variant IVS2-12C >T was identified in about $1 \%$ of diabetic as well as nondiabetic populations (Johansen et al. 2005, Zouali et al. 1993) and IVS $8+18 \mathrm{G}>\mathrm{A}$ in about $1 \%$ of diabetic population but not in healthy offspring or in the control population (Johansen et al. 2005, Lehto et al. 1999).

The detection rate of the above mentioned sequence variants, except of IVS9+8T $>C$, was much lower in our cohort of Czech diabetics type 2 and gestational diabetics in comparison with rates reported in French, Finnish and UK populations even after phenotypic selection for early-onset and family history of diabetes.

The silent substitution Tyr215Tyr $(645 \mathrm{C}>\mathrm{T})$ in exon 6 was detected across European populations and we confirmed its frequency about $1 \%$ in diabetic as well as non-diabetic subjects (Thomson et al. 2003, Johansen et al. 2005, Lehto et al. 1999, Zouali et al. 1993, Laakso et al. 1995). Ser263Ser (789C $>$ T) located in exon 7 was detected in one of our DM2 patients. Interestingly, the 
rare polymorphisms Ser263Ser and Tyr215Tyr were also identified in infants who died suddenly and unexpectedly (Forsyth et al. 2005).

The most common polymorphism is IVS9+8T $>$ C. We detected its minor allele in about $30 \%$ of both diabetic and non-diabetic populations. In other European populations, the frequency of this polymorphism was reported as being $36 \%$ in DM2 subjects and $27.5 \%$ in patients with IGT from Finland (Laakso et al. 1995), $15 \%$ in the MODY patients in UK (Thomson et al. 2003) and $14 \%$ in Italian families with early-onset DM2 (Gragnoli et al. 2001) or else the frequency was not stated: in French MODY and DM2 patients (Froguel et al. 1993), in Scandinavian subjects with early-onset DM2 and control population (Lehto et al. 1999) and in Danish MODY populations (Johansen et al. 2005). In intron 9, we also detected the polymorphism IVS9+49G $>A$ in frequencies varying from $\sim 7$ to $13 \%$ among groups. In the Italian subjects the frequency of the minor allele was about $3 \%$ (Gragnoli et al. 2001).

Six of the ten identified intronic variants in our study have not been previously described: IVS1 $+4 \mathrm{~T}>\mathrm{A}$, IVS3+9C $>$ T, IVS3-23C $>$ T, IVS4+26C $>$ A, IVS4+87C $>$ A and IVS7-15C $>$ G. On the other hand, we did not detect some of the intronic variants of $G C K$ that were identified in other European populations. The most often mentioned polymorphisms that we did not detect are: IVS2+11G $>$ A (Průhová et al. 2003, Johansen et al. 2005, Lehto et al. 1999, Zouali et al. 1993) and IVS7-7T>A (Johansen et al. 2005, Lehto et al. 1999).

\section{Conclusions}

We found a novel heterozygous missense mutation Val33Ala in exon 2 of the $G C K$ gene in a Czech MODY family. However, our study did not provide evidence of the GCK gene as a risk gene in the pathogenesis of diabetes mellitus type 2 or of gestational diabetes in the Czech population because we did not find any known $G C K$ pathogenic mutations in these subjects or any differences in the frequencies of $G C K$ polymorphisms between $\mathrm{Czech}$ diabetic and non-diabetic populations.

\section{Conflict of Interest}

There is no conflict of interest.

\section{Acknowledgements}

This study was supported by the grants IGA MH CR NR/7809-5.

\section{References}

BARRIO R, BELLANNÉ-CHANTELOT C, MORENO JC, MOREL V, CALLE H, ALONSO M, MUSTIELES C.: Nine novel mutations in maturity-onset diabetes of the young (MODY) candidate genes in 22 Spanish families. J Clin Endocrinol Metab 87: 2532-2539, 2002.

BYRNE MM, STURIS J, CLEMENT K, VIONNET N, PUEYO ME, STOFFEL M, TAKEDA J, PASSA P, COHEN D, BELL GI ET AL.: Insulin secretory abnormalities in subjects with hyperglycemia due glucokinase mutations. J Clin Invest 93: 1120-1130, 1994.

COSTA A, BESCOS M, VELHO G, CHEVRE J, VIDAL J, SESMILO G, BELLANNE-CHANTELOT C, FROGUEL P, CASAMITJANA R, RIVERA-FILLAT F, GOMIS R, CONGET I.: Genetic and clinical characterisation of maturity-onset diabetes of the young in Spanish families. Eur J Endocrinol 142: 380-386, 2000.

ELLARD S, BEARDS F, ALLEN LIS, SHEPHERD M, BALLANTYNE E, HARVEY R, HATTERSLEY AT: A high prevalence of glucokinase mutation in gestational diabetic subjects selected by clinical criteria. Diabetologia 43: 250-253, 2000.

FAJANS SS, BELL GI, POLONSKY KS: Molecular mechanisms and clinical pathophysiology of maturity-onset diabetes of the young. N Engl J Med 345: 971-980, 2001.

FORSYTH L, HUME R, HOWATSON A, BUSUTTIL A, BURCHELL A: Identification of novel polymorphisms in the glucokinase and glucose-6-phosphatase genes in infants who died suddenly and unexpectedly. J Mol Med 83: 610-618, 2005.

FROGUEL P, ZOUALI H, VIONNET N, VELHO G, VAXILLAIRE M, SUN F, LESAGE S, STOFFEL M, TAKEDA J, PASSA P, PERMUTT MA, BECKMANN JS, BELL GI, COHEN D: Familial hyperglycemia due to mutations in glucokinase -- definition of a subtype of diabetes mellitus. N Engl J Med 328: 697-702, 1993. 
GLOYN AL: Glucokinase (GCK) mutations in hyper- and hypoglycemia: maturity-onset diabetes of the young, permanent neonatal diabetes, and hyperinsulinemia of infancy. Hum Mutat 22: 353-362, 2003.

GRAGNOLI C, COCKBURN BN, CHIARAMONTE F, GORINI A, MARIETTI G, MAROZZI G, SIGNORINI AM: Early-onset Type II diabetes mellitus in Italian families due to mutations in the genes encoding hepatic nuclear factor 1 alpha and glucokinase. Diabetologia 44: 1326-1329, 2001.

HATTERSLEY AT: Molecular genetics goes to the diabetes clinic. Clin Med 5: 476-481, 2005.

JOHANSEN A, EK J, MORTENSEN HB, PEDERSEN O, HANSEN T: Half of clinically defined maturity-onset diabetes of the young patients in Denmark do not have mutations in HNF4A, GCK, and TCF1. J Clin Endocrinol Metab 90: 4607-4614, 2005.

LAAKSO M, MALKKI M, KEKALAINEN P, KUUSISTO J, MYKKANEN L, DEEB SS: Glucokinase gene variants in subjects with late-onset NIDDM and impaired glucose tolerance. Diabetes Care 18: 398-400, 1995.

LEDERMANN HM: Is maturity onset diabetes of the young age (MODY) more common in Europe than previously assumed? Lancet 345: 648, 1995.

LEHTO M, WIPEMO C, IVARSSON SA, LINDGREN C, LIPSANEN-NYMAN M, WENG J, WIBELL L, WIDEN E, TUOMI T, GROOP L: High frequency of mutations in MODY and mitochondrial genes in Scandinavian patients with familial early-onset diabetes. Diabetologia 42: 1131-1137, 1999.

LINDNER TH, COCKBURN BN, BELL GI: Molecular genetics of MODY in Germany. Diabetologia 42: 121-123, 1999.

MANTOVANI V, SALARDI S, CERRETA V, BASTIA D, CENCI M, RAGNI L, ZUCCHINI S, PARENTE R, CICOGNANI A: Identification of eight novel glucokinase mutations in Italian children with maturity-onset diabetes of the young. Hum Mutat 22: 338, 2003.

MASSA O, MESCHI F, CUESTA-MUNOZ A, CAUMO A, CERUTTI F, TONI S, CHERUBINI V, GUAZZAROTTI L, SULLI N, MATSCHINSKY FM, LORINI R, IAFUSCO D, BARBETTI F: High prevalence of glucokinase mutations in Italian children with MODY. Influence on glucose tolerance, first-phase insulin response, insulin sensitivity and BMI. Diabetes Study Group of the Italian Society of Paediatric Endocrinology and Diabetes (SIEDP). Diabetologia 44: 898-905, 2001.

MATSCHINSKY FM, LIANG Y, KESAVAN P, WANG L, FROGUEL P, VELHO G, COHEN D, PERMUTT MA, TANIZAWA Y, JETTON TL, NISWENDER K, MAGNUSON MA: Glucokinase as pancreatic beta cell glucose sensor and diabetes gene. J Clin Invest 92: 2092-2098, 1993.

MATSUDA M, DEFRONZO RA: Insulin sensitivity indices obtained from oral glucose tolerance testing: comparison with the euglycemic insulin clamp. Diabetes Care 22:1462-1470, 1999.

MATTHEWS DR, HOSKER JP, RUDENSKI AS, NAYLOR BA, TREACHER DF, TURNER RC: Homeostasis model assessment: insulin resistance and beta-cell function from fasting plasma glucose and insulin concentrations in man. Diabetologia 28:412-419, 1985.

OWEN K, HATTERSLEY AT: Maturity-onset diabetes of the young: From clinical description to molecular genetic characterization. Best Pract Res Clin Endocrinol Metab 15: 309-323, 2001.

PRŮHOVÁ S, EK J, LEBL J, ŠUMNÍK Z, SAUDEK F, ANDĚL M, PEDERSEN O, HANSEN T: Genetic epidemiology of MODY in the Czech republic: new mutations in the MODY genes HNF-4alpha, GCK and HNF-1alpha. Diabetologia 46: 291-295, 2003.

SCHUIT FC, HUYPENS P, HEIMBERG H, PIPELEERS DG: Glucose sensing in pancreatic beta-cells: a model for the study of other glucose-regulated cells in gut, pancreas, and hypothalamus. Diabetes 50: 1-11, 2001.

STOFFEL M, FROGUEL P, TAKEDA J, ZOUALI H, VIONNET N, NISHI S, WEBER IT, HARRISON RW, PILKIS SJ, LESAGE S, VAXILLAIRE M, VELHO G, SUN F, IRIS F, PASSA P, COHEN D, BELL GI: Human glucokinase gene: isolation, characterization, and identification of two missense mutations linked to earlyonset non-insulin-dependent (type 2) diabetes mellitus. Proc Natl Acad Sci USA 89: 7698-7702, 1992.

THOMSON KL, GLOYN AL, COLCLOUGH K, BATTEN M, ALLEN LI, BEARDS F, HATTERSLEY AT, ELLARD S: European Caucasians with maturity-onset diabetes of the young (MODY). Hum Mutat 22: 417 , 2003. 
VELHO G, BLANCHE H, VAXILLAIRE M, BELLANNE-CHANTELOT C, PARDINI VC, TIMSIT J, PASSA P, DESCHAMPS I, ROBERT JJ, WEBER IT, MAROTTA D, PILKIS SJ, LIPKIND GM, BELL GI, FROGUEL P: Identification of 14 new glucokinase mutations and description of the clinical profile of 42 MODY-2 families. Diabetologia 40: 217-224, 1997.

ZOUALI H, VAXILLAIRE M, LESAGE S, SUN F, VELHO G, VIONNET N, CHIU K, PASSA P, PERMUTT A, DEMENAIS F, COHEN D, BECKMAN JS, FROGUEL P: Linkage analysis and molecular scanning of glucokinase gene in NIDDM families. Diabetes 42: 1238-1245, 1993. 